\begin{tabular}{|c|c|}
\hline Title & I ridium-Catalyzed Direct A symmetric A Ikylation of A niline Derivatives using 2-Norbornene \\
\hline Author(s) & Shirai, Tomohiko; Okamoto, Takakazu; Y amamoto, Y asunori \\
\hline Citation & $\begin{array}{l}\text { A sian journal of organic chemistry, 7(6), } 10541056 \\
\text { https://doi.org/10.1002/ajoc.201800185 }\end{array}$ \\
\hline Issue Date & 201806 \\
\hline Doc URL & http:/hdl.handle.net/2115/74509 \\
\hline Rights & $\begin{array}{l}\text { This is the peer-reviewed version of the following article: A sian journal of organic chemistry } 7(6) \text { pp.1054-1056, } \\
\text { which has been published in final form at https://doi.org/AO.1002/ajoc. } 201800185 \text {. This article may be used for non- } \\
\text { commercial purposes in accordance with Wiley-V VH Terms and Conditions for Self-A rchiving. }\end{array}$ \\
\hline Type & article (author version) \\
\hline File Information & Iridium-Catalyzed Direct A symmetric A Ikylation of A niline Derivatives using 2-Norbornene.pdf \\
\hline
\end{tabular}

Instructions for use 


\title{
Iridium-Catalyzed Direct Asymmetric Alkylation of Aniline Derivatives using 2-Norbornene
}

\author{
Tomohiko Shirai ${ }^{*[a]}$, Takakazu Okamoto ${ }^{[a]}$, and Yasunori Yamamoto ${ }^{[b]}$
}

\begin{abstract}
We investigate an efficient and highly enantioselective direct alkylation process for acetanilides that use 2-norbornene with a bis(phosphoramidite)-cationic Ir catalytic system (up to $99 \%$ ee). This methodology allows the facile preparation of enantiomerically enriched exo-2-(bicyclo[2.2.1]heptan-2-yl)aniline, which can be readily transformed into other functionalities.
\end{abstract}

Enantioselective transformations through the activation of $\mathrm{C}-\mathrm{H}$ bond depict a potential to become an ideal tool for the synthesis of chiral building blocks. ${ }^{[1]}$ Recently, transition-metal-catalyzed asymmetric direct additions of $\mathrm{C}-\mathrm{H}$ bond have become impressive synthetic methods for building useful functionalized molecules from ubiquitous chemicals. ${ }^{[2-5]}$ Our research group has already demonstrated that the cationic $\operatorname{Ir}(\mathrm{I}) / \mathrm{Me}-\mathrm{BIPAM}$ complexes can catalyze the asymmetric direct addition of $\mathrm{C}\left(\mathrm{sp}^{2}\right)-\mathrm{H}$ bonds to unsaturated compounds such as $\mathrm{C}=\mathrm{O}$ and $\mathrm{C}=\mathrm{C}^{[6]}$ In 2015, we reported the first highly enantioselective intermolecular direct addition of $\mathrm{C}\left(\mathrm{sp}^{2}\right)-\mathrm{H}$ bonds to bicycloalkenes (Scheme 1). ${ }^{[6 b]}$ In our reaction, an amide-based directing group (DG) depicted a better performance than that depicted ketone besed DG. However, it is difficult to convert tertiary amides to form other functionalities. ${ }^{[7]}$ In this context, aniline derivatives, such as acetanilide, can be conventionally prepared and readily transformed into other functional groups. To the best of our knowledge, very few examples of aniline derivatives-directed asymmetric $\mathrm{C}-\mathrm{C}$ bond formation through $\mathrm{C}-$ $\mathrm{H}$ bond activation have been reported. Shibata and co-workers developed the first acetanilide directed cationic iridium/chiral bis(phosphine) complex-catalyzed enantioselective $\mathrm{C}-\mathrm{H}$ conjugate addition to the $\alpha, \beta$-unsaturated carbonyl compounds. However, the products were only obtained in moderate yields with good enantioselectivity. ${ }^{[3 \mathrm{~h}]}$ Therefore, no systems are observed to exist for the aniline derivatives-directed intermolecular asymmetric $\mathrm{C}-\mathrm{H}$ addition to alkenes with high efficiency and high enantioselectivity. In this study, we describe the iridium/(R,R)-S-Me-BIPAM-catalyzed direct asymmetric alkylation of acetanilides using 2-norbornene.

We initiated our investigations by studying the reaction parameters, such as the precursors, chiral ligands and solvents

[a] Dr. T. Shirai, T. Okamoto

Department of Materials Science and Engineering

National Institute of Technology, Kochi College

Otsu Monobe, Nankoku, Kochi 783-8508 (Japan)

E-mail: shira@@kochi-ct.ac.jp

[b] Prof. Dr. Y. Yamamoto

Division of Chemical Process Engineering and Frontier Chemistry

Center (FCC), Faculty of Engineering

Hokkaido University, Kita 13 Nishi 8 Kita-ku, Sapporo

Hokkaido 060-8628 (Japan)

Supporting information for this article is given via a link at the end of the document. in asymmetric direct alkylation of 2-methylacetanilide (1a) with 2norbornene (Table 1). 1a was selected to be the model substrate in order to avoid the complication of overalkylation.

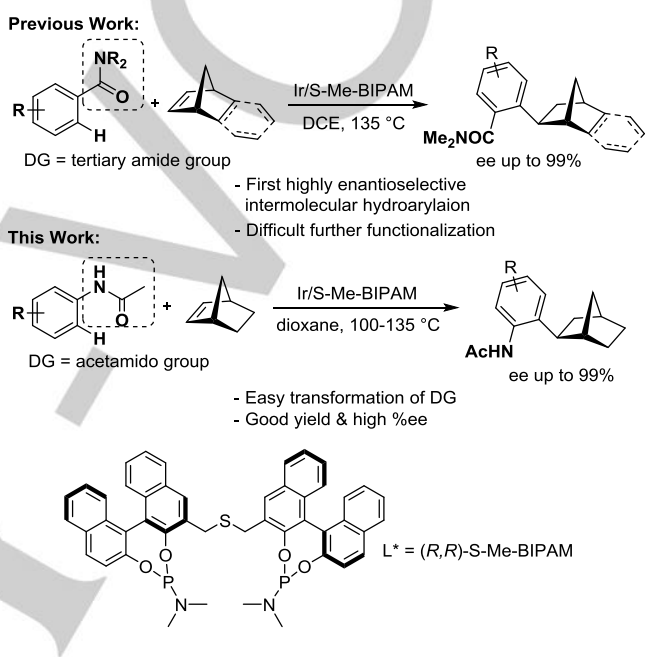

Scheme 1. Enantioselective intermolecular alkylation with bicycloalkenes.

Table 1. Optimization of the reaction conditions. ${ }^{[a]}$
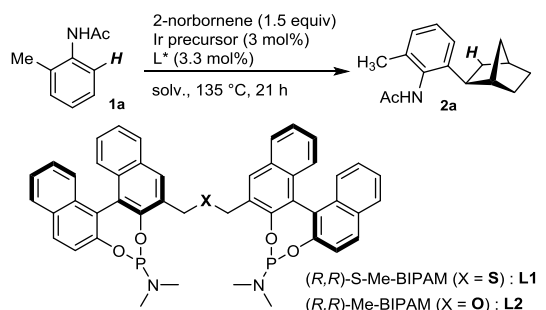

\begin{tabular}{|c|c|c|c|c|c|}
\hline entry & Precursor & $\mathrm{L}^{*}$ & Solvent & Yield $[\%]^{[b]}$ & ee $[\%]^{[c]}$ \\
\hline 1 & {$[\operatorname{lr}(\operatorname{cod}) \mathrm{Cl}]_{2}$} & L1 & DCE & n.r. & - \\
\hline 2 & $\operatorname{Ir}(\operatorname{cod})_{2}\left(\mathrm{BF}_{4}\right)$ & L1 & DCE & 39 & 99 \\
\hline 3 & $\operatorname{Ir}(\operatorname{cod})_{2}\left(\mathrm{BAr}_{4}{ }_{4}\right)$ & L1 & DCE & 89 & 97 \\
\hline 4 & $\operatorname{Ir}(\operatorname{cod})_{2}\left(\mathrm{BAr}_{4}{ }_{4}\right)$ & $\mathrm{L} 2$ & DCE & 52 & 73 \\
\hline $5^{[\mathrm{d}]}$ & $\operatorname{Ir}(\operatorname{cod})_{2}\left(\mathrm{BAr}_{4}\right)$ & $\mathrm{L}^{*}$ & DCE & 8 & 12 \\
\hline $6^{[\mathrm{e}]}$ & $\operatorname{Ir}(\operatorname{cod})_{2}\left(\mathrm{BAr}_{4}\right)$ & $L^{*}$ & DCE & 77 & 20 \\
\hline 7 & $\operatorname{Ir}(\operatorname{cod})_{2}\left(\mathrm{BAr}_{4}{ }_{4}\right)$ & L1 & Toluene & 90 & 93 \\
\hline 8 & $\operatorname{Ir}(\operatorname{cod})_{2}\left(\mathrm{BAr}_{4}\right)$ & L1 & DME & 69 & 97 \\
\hline 9 & $\operatorname{Ir}(\operatorname{cod})_{2}\left(\mathrm{BAr}_{4}\right)$ & L1 & THF & 71 & 99 \\
\hline 10 & $\operatorname{Ir}(\operatorname{cod})_{2}\left(\mathrm{BAr}_{4}\right)$ & L1 & Dioxane & 92 & 97 \\
\hline $11^{[\mathrm{ff}]}$ & $\operatorname{Ir}(\operatorname{cod})_{2}\left(\mathrm{BAr}_{4}\right)$ & L1 & Dioxane & 83 & 97 \\
\hline
\end{tabular}

[a] Reaction conditions: 1a $(0.25 \mathrm{mmol}), 2$ (3.5 equiv), Ir cat. ( $5 \mathrm{~mol} \%)$, and chiral ligand ( 1.1 equiv to $\mathrm{Ir}$ ) in solvent, stirred for $21 \mathrm{~h}$ at $135^{\circ} \mathrm{C}$. [b] Isolated yield. n.r. = no reaction. [c] Determined by HPLC analysis. [d] $(R)$ - 
BINAP was used. [e] (R)-Monophos was used. [f] At $100^{\circ} \mathrm{C}$.

As shown in the entries 1-3 of Table 1, alkylation in the presence of $5 \mathrm{~mol} \%[\operatorname{lr}(\operatorname{cod}) \mathrm{Cl}]_{2}$ and $(R, R)-S-M e-B I P A M$ in DCE at $135^{\circ} \mathrm{C}$ did not yield 2a. When $\left[\operatorname{lr}(\operatorname{cod})_{2}\right]\left(\mathrm{BAr}_{4}\right)$ was used, the reaction proceeded smoothly to afford the alkylated product in high yield and excellent enantioselectivity (entry 3, 89\%, 97\% ee). However, the use of $(R)$-BINAP or $(R)$-Monophos caused reduced yields and low enantioselectivities (entries 5-6). The solvent had some effect on the yield and enantioselectivity (entries 7-10), and the highest yields could be obtained using $135^{\circ} \mathrm{C}$ to $100^{\circ} \mathrm{C}$ slightly decreased the yield; however, excellent enantioselectivity was obtained. (entry $11,83 \%, 97 \%$ ee).

We further explored the applicability of the optimized asymmetric alkylation conditions to various aniline derivatives (1a-1n), (Table 2). Differently substituted aniline derivatives (1a-1d) furnished the corresponding products (2a-2d) in good yields with high enantioselectivities. Hydrocarbon substituents, such as the ethyl, isopropyl, and t-butyl groups, on the amide structure did not interfere with the enantioselectivity. At the current level of development, carbamates and other tertiary amides were observed to be not suitable to serve as DGs (2e, 2f). On the arene moiety, an extensive range of substituents, including $\mathrm{Me}, \mathrm{OMe}, \mathrm{Cl}$, and $\mathrm{CO}_{2} \mathrm{Me}$, were tolerated $(\mathbf{2} \mathbf{g}-\mathbf{2} \mathbf{j}$; see supporting information for additional details). 1,4-dioxane (entry 10). Lowering the reaction temperature from

The reaction of 2,3- or 2,4-disubstituted acetanilides (1k-1m) with 2-norbornene also produced the desired products $(\mathbf{2} \mathbf{k}-\mathbf{2 m})$ in good yields with high enantioselectivities. Unfortunately, 2chloroacetanilide was not suitable for this reaction. In contrast to our previous study, dialkylation was only observed in case of the unsubstituted acetanilide (20,86\%, the enantioselectivity could not be determined). These results suggest that the mono- or dialkylation selectivity is dependent on the ease of bond rotation in the DG.

The acetamido group of product $\mathbf{2 g}$ was readily eliminated by treat with aqueous $\mathrm{NaOH}$ to produce the corresponding aniline (3) in a yield of $84 \%$ (Scheme 2). ${ }^{[8]}$

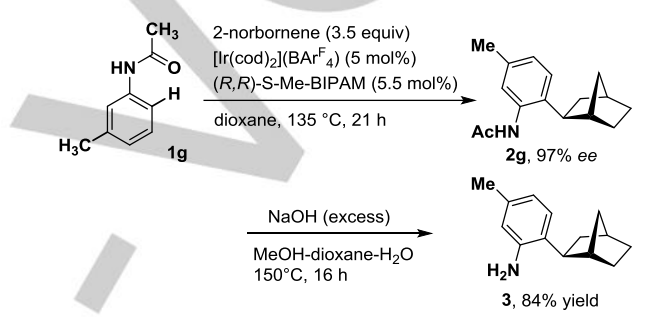

Scheme 2. Hydrolysis of $\mathbf{2 g}$ with aqueous $\mathrm{NaOH}$.

A catalytic cycle involving $\mathrm{C}-\mathrm{H}$ activation, insertion of the $\mathrm{C}=\mathrm{C}$ bond into the Aryl-Ir bond, and formation of the $\mathrm{C}-\mathrm{H}$ bond causing reductive elimination has been already proposed in our previous study. ${ }^{[6]}$ To gain an additional insight into the reaction mechanism, we performed $D_{2} \mathrm{O}$ experiments (Scheme 3). Exposure of 3-methylacetanilide (19) to $\operatorname{Ir}(\operatorname{cod})_{2}\left(\operatorname{BAr}_{4}{ }_{4}\right) /(R, R)$-SMe-BIPAM with $\mathrm{D}_{2} \mathrm{O}$ in the absence of 2-norbornene caused a deuterium-incorporation of $78 \%$ in the $\mathrm{C} 6$ position and of $<5 \%$ in the $\mathrm{C} 2$ position. Furthermore, the same reaction was conducted with $\mathrm{D}_{2} \mathrm{O}$ in the presence of 2-norbornene, and a deuteriumincorporation of $67 \%$ was observed in $\mathrm{C} 6$ position. The observation of $\mathrm{H} / \mathrm{D}$ scrambling may illustrate that the $\mathrm{C}-\mathrm{H}$ activation step is reversible (Figure 1). A similar deuterium experiment was conducted using 2-chloroacetanilide (1n). No deuterium incorporation was observed in the ortho position under catalytic conditions, which suggested that the chloro group negatively affects the $\mathrm{C}-\mathrm{H}$ bond activation.

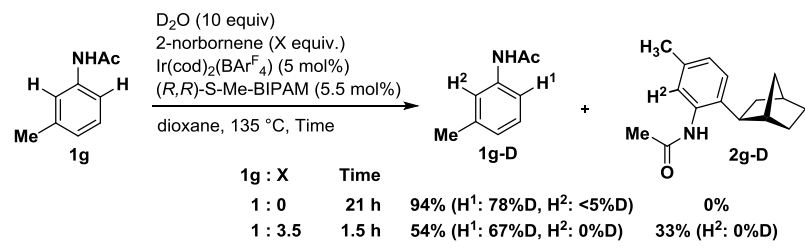

Scheme 3. Deuterium-incorporation in substrate $\mathbf{1 g}$.

[a] Reaction conditions: 1a $(0.25 \mathrm{mmol}), 2$ (3.5 equiv), $\operatorname{Ir}(\mathrm{cod})_{2}\left(\mathrm{BAr}_{4}{ }_{4}\right)(5$ mol\%), and $(R, R)$-S-Me-BIPAM (1.1 equiv to Ir) in 1,4-dioxane, stirred for $21 \mathrm{~h}$ at $135^{\circ} \mathrm{C}$. [b] Isolated yield. n.r. = no reaction. [c] Determined by HPLC analysis.
Thus, we developed a highly exo-selective ${ }^{[9]}$ and enantioselective direct alkylation of aniline derivatives using 2- 
norbornene catalyzed with the cationic $\operatorname{Ir} /(R, R)$-S-Me-BIPAM complex. Efforts to extend the scope of the enantioselective alkylation of aniline derivatives with unstrained alkenes and mechanistic investigations are currently underway.

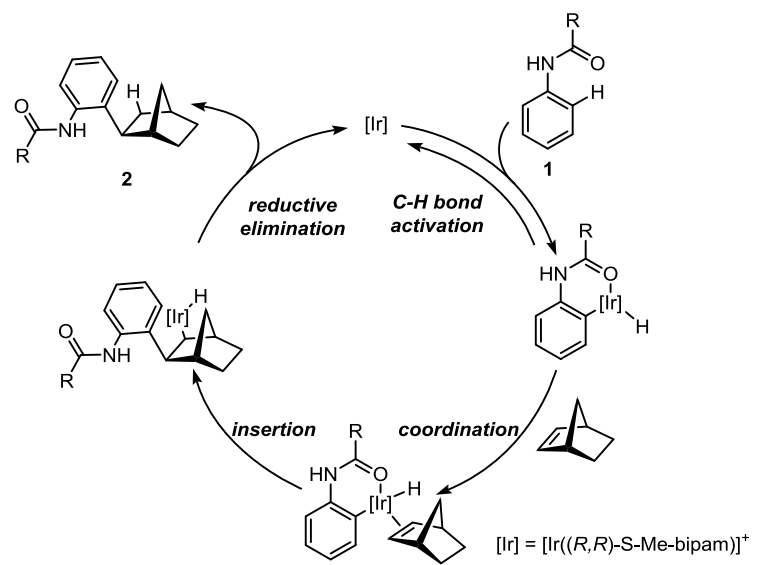

Figure 1. The proposed catalytic cycle.

\section{Experimental Section}

General procedure: To a flame-dried flask, $\left[\mathrm{Ir}(\operatorname{cod})_{2}\right]\left(\mathrm{BAr}_{4}{ }_{4}\right)(0.0125 \mathrm{mmol}$, $5 \mathrm{~mol} \%),(R, R)$-S-Me-BIPAM (0.0138 mmol, $5.5 \mathrm{~mol} \%)$, and 1,4-dioxane $(1.0 \mathrm{~mL})$ were added under an $\mathrm{N}_{2}$-atmosphere. The solution was stirred at room temperature for $30 \mathrm{~min}$. Thereafter, acetanilide $(0.25 \mathrm{mmol})$ and 2-norbornene (3.5 equiv.) were added. The reaction mixture was further heated to $135{ }^{\circ} \mathrm{C}$ and stirred for $24 \mathrm{~h}$. The cooled mixture was purified using silica gel column chromatography (eluent: hexane/AcOEt) to afford pure hydroarylated product.

\section{Acknowledgements}

This work was supported by JSPS KAKENHI No.16H07402, Japan.

Keywords: alkylation • bicycloalkene $\cdot$ Me-BIPAM • iridium • acetanilide

[1] For selected recent reviews for enantioselective $\mathrm{C}-\mathrm{H}$ functionalization, a) S. Pan, T. Shibata, ACS Catal. 2013, 3, 704-712; b) S. Motevalli, Y. Sokeirik, A. Ghanem. Eur. J. Org. Chem. 2016, 1459-1475; c) C. G. Newton, S.-G. Wang, C. C. Oliveira, N. Cramer, Chem. Rev. 2017, 117, 8908-8976; d) Z. Dong, Z. Ren, S. J. Thompson, Y. Xu, G. Dong, Chem. Rev. 2017, 117, 9333-9403.

[2] For asymmetric direct heteroaromatic $\mathrm{C}-\mathrm{H}$ bond to alkenes, a) $\mathrm{R}$. $\mathrm{M}$. Wilson, R. K. Thalji, R. G. Bergman, J. A. Ellman, Org. Lett. 2006, 8, 1745-1747; b) J. C. Rech, M. Yato, D. Duckett, B. Ember, P. V. LoGrasso, R. G. Bergman, J. A. Ellman, J. Am. Chem. Soc. 2007, 129, 490-491; c) A. S. Tsai, R. M. Wilson, H. Harada, R. G. Bergman, J. A. Ellman, Chem. Commun. 2009, 3910-3912; d) S. Pan, N. Ryu, T. Shibata, J. Am. Chem. Soc. 2012, 134, 17474-17477; e) C. S. Sevov, J.
F. Hartwig, J. Am. Chem. Soc. 2013, 135, 2116-2119; f) G. Song, W. W. N. O, Z. Hou, J. Am. Chem. Soc. 2014, 136, 12209-12212; g) P.-S. Lee, N. Yoshikai, Org. Lett. 2015, 17, 22-25; h) C. M. Filloux, T. Rovis, J. Am. Chem. Soc. 2015, 137, 508-517; i) T. Shibata, N. Ryu, H. Takano, Adv. Synth. Catal. 2015, 357, 1131-1135; j) J. S. Marcum, C. C. Roberts, R. S. Manan, T. N. Cervarich, S. J. Meek, J. Am. Chem. Soc. 2017, 139, 15580-15583.

[3] For asymmetric intermolecular addition of $\mathrm{C}\left(\mathrm{sp}^{2}\right)-\mathrm{H}$ bond to alkenes, a) R. Aufdenblatten, S. Diezi, A. Togni, Monatsh. Chem. 2000, 131, 1345 1350; b) F. Kakiuchi, P. L. Gendre, A. Yamada, H. Ohtaki, S. Murai, Tetrahedron Asymmetry 2000, 11, 2647-2651; c) R. Dorta, A. Togni, Chem. Commun. 2003, 760-761; d) K. Tsuchikama, M. Kasagawa, Y. Hashimoto, K. Endo, T. Shibata, J. Organomet. Chem. 2008, 693, 3939-3942; e) T. Shibata, T. Shizuno, Angew. Chem. Int. Ed. 2014, 53, 5410-5413; Angew. Chem. 2014, 126, 5514-5517; f) Y. Ebe, T. Nishimura, J. Am. Chem. Soc. 2015, 137, 5899-5902; g) M. Hatano, Y. Ebe, T. Nishimura, H. Yorimitsu, J. Am. Chem. Soc. 2016, 138, 40104013; h) T. Shibata, M. Michino, H. Kurita, Y.-K. Tahara, K. S. Kanyiva, Chem. Eur. J. 2017, 23, 88-91; i) D. Yamauchi, T. Nishimura, H. Yorimitsu, Chem. Commun. 2017, 53, 2760-2763; j) M. Nagamoto, T. Nishimura, ACS Catal. 2017, 7, 833-847; k) M. Nagamoto, J.-I. Fukuda M. Hatano, H. Yorimitsu, T. Nishimura, Org. Lett. 2017, 19, 5952-5955.

[4] For asymmetric intramolecular addition of $\mathrm{C}\left(\mathrm{sp}^{2}\right)-\mathrm{H}$ bond to alkenes, a) R. K. Thalji, J. A. Ellman, R. G. Bergman, J. Am. Chem. Soc. 2004, 126, 7192-7193; b) S. H. Wiedemann, J. C. Lewis, J. A. Ellman, R. G. Bergman, J. Am. Chem. Soc. 2006, 128, 2452-2462; c) H. Harada, R. K, Thalji, R. G. Bergman, J. A. Ellman, J. Org. Chem. 2008, 73, 67726779; d) B. Ye, P. A. Donets, N. Cramer, Angew. Chem. Int. Ed. 2014, 53, 507-511; Angew. Chem. 2014, 126, 517-521; e) D. F. Fernandez, M. Gulias, J. L. Mascarenas, F. Lopez, Angew. Chem. Int. Ed. 2017, 56, 9541-9545; Angew. Chem. 2017, 129, 9669-9673.

[5] For asymmetric alkylation of $\mathrm{C}\left(\mathrm{sp}^{3}\right)-\mathrm{H}$ bond, a) Z. Li, C.-J. Li, Org. Lett. 2004, 6, 4997-4999; b) P. Eisenberger, R. O. Ayinla, J. M. P. Lauzon, L. L. Schafer, Angew. Chem. Int. Ed. 2009, 48, 8361-8365; Angew. Chem. 2009, 125, 9314-9318; c) G. Li, F. Zhang, H. Song, Chem. Commun 2010, 46, 6296-6298; d) F. Zhang, H. Song, G. Li, Dalton Trans. 2011, 40, 1547-1566; e) S. Pan, K. Endo, T. Shibata, Org. Lett. 2011, 13 4692-4695; f) Q. Li, Z.-X. Yu, Angew. Chem. Int. Ed. 2011, 50, 21442147; Angew. Chem. 2011, 123, 2192-2195; g) A. L. Reznichenko, T. J. Emge, S. Audorsch, E.G. Klauber, K. C. Hultzsch, B. Schmidt, Organometallics 2011, 30, 921-924; h) A. L. Reznichenko, K. C. Hultzsch, J. Am. Chem. Soc. 2012, 134, 3300-3311; i) S. Pan, Y. Matsuo, K. Endo, T. Shibata, Tetrahedron 2012, 68, 9009-9015; j) Y.-K. Tahara, M. Michino, M. Ito, K. S. Kanyiva, T. Shibata, Chem. Commun. 2015, 51, 16660-16663; k) T. Torigoe, T. Ohmura, M. Suginome, Angew. Chem. Int. Ed. 2017, 56, 14272-14276; Angew. Chem. 2017, 129, 14460-14464.

[6] a) T. Shirai, H. Ito, Y. Yamamoto, Angew. Chem. Int. Ed. 2014, 53 , 2658-2661; Angew. Chem. 2014, 126, 2696-2699; b) T. Shirai, Y. Yamamoto, Angew. Chem. Int. Ed. 2015, 54, 9894-9897; Angew. Chem. 2015, 127, 10032-10035; c) T. Shirai, Y. Yamamoto, Organometallics, 2015, 34, 3459-3463.

[7] a) L. Hie, N. F. F. Nathel, T. K. Shah, E. L. Baker, X. Hong, Y.-F. Yang, P. Liu, K. N. Houk, N. K. Garg, Nature, 2015, 524, 79-83; b) A. Volkov, F. Tinnis, T. Stagbrand, P. Trillo, H. Adolfsson, Chem. Soc. Rev. 2016, 45, 6685-6697.

[8] G. E. M. Crisenza, O. O. Sokolova, J. F. Bower, Angew. Chem. Int. Ed. 2015, 54, 14866-14870; Angew. Chem. 2015, 127, 15079-15083.

[9] Unusual endo-selective hydroarylation of bicycloalkene; K. Shibata, S Natsui, M. Tobisu, Y. Fukumoto, N. Chatani, Nat. Commun. 2017, 8 1448 . 


\section{Entry for the Table of Contents}

\section{COMMUNICATION}

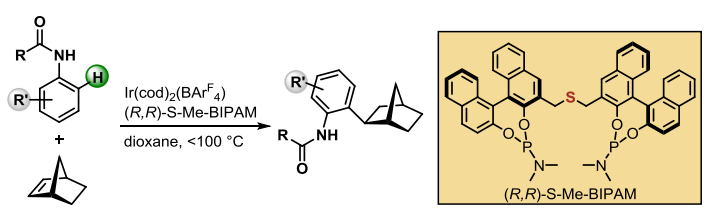

We investigate an efficient and highly enantioselective direct alkylation process for acetanilides that use 2-norbornene with a bis(phosphoramidite)-cationic Ir catalytic system (up to $99 \%$ ee). This methodology allows the facile preparation of enantiomerically enriched exo-2-(bicyclo[2.2.1]heptan-2-yl)aniline, which can be readily transformed into other functionalities.
T. Shirai*, T. Okamoto, Y. Yamamoto

Page No. - Page No.

Iridium-Catalyzed Direct Asymmetric Alkylation of Aniline Derivatives with 2-Norbornene 